\title{
Ratio of blood and marrow-derived cells in bone marrow transplantation
}

\author{
HEM KAY, HILARY LUMLEY, HMCD CLINK, RL POWLES \\ From the Leukaemia Unit, Royal Marsden Hospital, Fulham Road, London SW3 6JJ, and the Institute \\ of Cancer Research, Sutton, Surrey
}

SUMMARY The content of the cell suspensions used in bone marrow transplantation can vary by at least twelvefold in the ratio of bone marrow-derived to blood-derived cells. The ratio is somewhat higher in young donors but is similar for male and female donors and is not closely correlated with the incidence of graft $v$ host reactions.

In bone marrow transplantation in man, a mixture of blood and marrow is aspirated from the donor and injected intravenously to the recipient. To obtain enough cells (usually considered to be $\geqslant 2 \times 10^{8} / \mathrm{kg}$ body weight) the volume of aspirate must approach one litre, of which it can be assumed that $98 \%$ or so is actually blood and less than $2 \%$ is derived from the marrow itself. This cell mixture is in sharp contrast with that used in marrow transplants in mice, where femoral marrow cells form an inoculum which is virtually free of blood contamination. Furthermore, it is an old observation that in mice graft $v$ host $(\mathrm{G} v \mathrm{H})$ reactions are relatively uncommon and difficult to induce by such marrow suspensions, whereas the addition of blood, lymph node or spleen cells greatly enhances the incidence and severity of $\mathrm{G} v \mathrm{H}$ reactions. ${ }^{1}$ Similar observations in dogs and other species confirm the general validity of the hypothesis that it is cells from the blood-presumptively $\mathbf{T}$ lymphocytes-which are the precipitating cause of $\mathrm{G} v \mathrm{H}$ disease. ${ }^{2} 3$

What is not known is the actual composition of the blood-marrow mixture in human transplants and whether it is related to $\mathrm{G} v \mathrm{H}$ disease. In particular, the increased susceptibility to $\mathrm{G} v \mathrm{H}$ disease if the donor is female-irrespective of the recipient sex ${ }^{4}$-might result from differences in the content of the donor inoculum perhaps because the volume of accessible marrow was smaller in women and hence dilution with blood cells was greater.

Accordingly, we have analysed the components of the marrow-blood mixture as given to 42 patients in the last $2 \frac{1}{2}$ years.

\section{Material and methods}

Marrow is aspirated under general anaesthesia from the iliac crests, anterior and posterior, and from the sternum of all donors. Occasionally other sites, such as the superior portions of the ala of the sacrum, the greater trochanters and tibias have been aspirated. The donors have all had normal blood counts and in most instances, the red cells and plasma from one unit of donor blood, taken one week earlier, are retransfused to restore, at least partially, the blood volume. Donors receive heparin $1500 \mathrm{U} / \mathrm{m}^{2}$ and the aspirate is collected in bags with $3000 \mathrm{U}$ heparin. These bags, usually three, are weighed to indicate the volume collected and an aliquot is taken for counting total nucleated cells in a Coulter $F$ model counter.

Aspiration is continued until enough cells have been removed to give at least $2 \times 10^{8} / \mathrm{kg}$ of the recipient's body weight. In a few instances it has been difficult to procure enough cells, but in general, since all except three donors have been aged $13 \mathrm{yr}$ or over, the possible disproportion in donor and recipient size has not been a problem. All but six of the donors have had blood counts at the Royal Marsden Hospital before the donation; serial counts throughout the donation in a sample of donors have shown no significant change so that in the other six it has been possible to calculate the data from a blood count performed after the donation.

A few attempts were made to measure the lymphocyte content of the aspirates from May-GrünwaldGiemsa stained films but the accuracy of this procedure is very low. In addition to smudge cells the marrow contains many ambiguous cells, possibly 
lymphocytes, possibly precursor cells or cells of the erythropoietic series-this makes a precise analysis almost impossible. Knowing the volume of marrow-blood aspirate and the blood leucocyte count, it is possible to estimate the proportion of blood-derived lymphocytes; thence by subtraction from the total nucleated cell content the number of bone marrow cells can be calculated. Separate analysis of each bag shows some variation between bags with maximum marrow cell yields in the first bag and with higher concentrations of marrow cells from the sternum as compared to the iliac crests.

\section{Results}

Tables 1 and 2 show the data from 42 donors aged 5-52 yr, together with information relating to marrow engraftment and $\mathrm{G} v \mathrm{H}$ disease etc. All the recipients, except three (with chronic granulocytic leukaemia), have had acute myeloid leukaemia in either first, second or third remission. All but the three sets of identical twins were treated with cyclosporin A (CsA) as immunosuppressant. Some mismatched patients also received three doses of methotrexate immediately after transplant.

It will be seen that there is a fairly wide range of marrow cells aspirated but it must be realised that the volume and yield is to some extent determined by the size of the recipient and by knowledge of the yield, bag by bag, as the aspiration proceeds. In a few cases-for example, case Nos 82 and 102, suboptimal cell numbers were obtained leading to high volume donations. However only one marrow failed to take, case No 71. This was a low-yield aspirate but a second donation (of even lower yield) was successful.

Analysing the adult donors separately (age $22 \mathrm{yr}$ and over) it can be seen that the ratio of bonemarrow cells to blood-derived cells varies from 0.4 to 5.1 and that the mean ratio for 10 females is higher (2.32) than for 22 males $(2 \cdot 02)$. The ratio for younger donors $(<22 \mathrm{yr})$ is somewhat higher $(2 \cdot 85)$ as might be expected from the greater cellularity of young bone-marrow and the rather smaller quantity of aspirate.

There is no close correlation in this series between

Table 1 Data relating to 29 male donor aspirates. All figures $\times 10^{8}$ unless otherwise stated

\begin{tabular}{|c|c|c|c|c|c|c|c|c|c|c|c|c|c|c|}
\hline \multirow[t]{2}{*}{ Case no } & \multirow[t]{2}{*}{ Age $(y r)$} & \multirow[t]{2}{*}{$\operatorname{Vol}(\mathrm{ml})$} & \multirow{2}{*}{$\begin{array}{l}\text { Total } \\
\text { cells }\end{array}$} & \multirow{2}{*}{$\begin{array}{l}\text { Cells/kg } \\
\text { recipients } \\
\text { body } \\
\text { weight }\end{array}$} & \multicolumn{2}{|l|}{ Donor } & \multirow{2}{*}{$\begin{array}{l}\text { Blood- } \\
\text { derived } \\
\text { cells } \\
(B D C)\end{array}$} & \multirow{2}{*}{$\begin{array}{l}\text { BDC!kg } \\
\text { recipients } \\
\text { body } \\
\text { weight }\end{array}$} & \multirow{2}{*}{$\begin{array}{l}\text { Blood } \\
\text { derived } \\
\text { lymphs } \\
(B D L)\end{array}$} & \multirow{2}{*}{$\begin{array}{l}\text { BDL/kg } \\
\text { recipients } \\
\text { body } \\
\text { weight }\end{array}$} & \multirow{2}{*}{$\begin{array}{l}\text { Bone } \\
\text { marrow } \\
\text { cells } \\
(B M C)\end{array}$} & \multirow{2}{*}{$\begin{array}{l}B M C / \\
B D C\end{array}$} & \multirow{2}{*}{$\begin{array}{l}\text { Type } \\
\text { of } \\
\text { grafi* }\end{array}$} & \multirow[t]{2}{*}{$G v H(e t c) \dagger$} \\
\hline & & & & & $\begin{array}{l}W B C \\
\left(\times 10^{9} / l\right)\end{array}$ & Lymphs $(\%)$ & & & & & & & & \\
\hline 88 & 5 & 946 & 227 & $3 \cdot 3$ & $4 \cdot 4$ & 46 & 42 & 0.61 & 19 & 0.28 & 185 & $4 \cdot 4$ & $\mathrm{C}$ & Mild \\
\hline 49 & 9 & 478 & 157 & $3 \cdot 0$ & $7 \cdot 7$ & 28 & 38 & 0.72 & $10 \cdot 2$ & 0.19 & 120 & $3 \cdot 2$ & C & 0 \\
\hline 67 & 14 & 468 & 104 & $3 \cdot 7$ & $5 \cdot 7$ & 32 & 27 & 0.95 & $8 \cdot 5$ & $0 \cdot 3$ & 77 & $2 \cdot 8$ & $\mathrm{C}$ & Mild \\
\hline 96 & 15 & 956 & 204 & $2 \cdot 8$ & $4 \cdot 7$ & 52 & 45 & 0.61 & $23 \cdot 4$ & 0.32 & 159 & $3 \cdot 5$ & $\mathrm{C}$ & Moderate \\
\hline 94 & 15 & 758 & 251 & $3 \cdot 3$ & $5 \cdot 8$ & 39 & 44 & 0.58 & $17 \cdot 1$ & $0 \cdot 22$ & 207 & $4 \cdot 7$ & $\mathbf{M}$ & Severe (fatal) \\
\hline 82 & 15 & 1840 & 193 & $2 \cdot 2$ & $6 \cdot 7$ & 59 & 123 & $1 \cdot 4$ & $72 \cdot 0$ & 0.82 & 79 & 0.6 & C & Moderate \\
\hline 60 & 16 & 782 & 203 & $3 \cdot 6$ & $6 \cdot 4$ & 27 & 50 & 0.89 & $13 \cdot 5$ & $0 \cdot 24$ & 153 & 3.05 & $\mathrm{C}$ & 0 \\
\hline 61 & 17 & 958 & 207 & $3 \cdot 2$ & $5 \cdot 0$ & & 48 & 0.74 & & & 159 & $3 \cdot 3$ & $\mathrm{C}$ & Mild \\
\hline 74 & 19 & 1033 & 209 & $3 \cdot 0$ & $6 \cdot 2$ & 31 & 64 & 0.92 & $20 \cdot 0$ & $0 \cdot 29$ & 145 & $2 \cdot 25$ & $\mathbf{M}$ & ARDS \\
\hline 54 & 20 & 980 & 207 & $3 \cdot 2$ & 8.9 & & 87 & $1 \cdot 34$ & & & 119 & $1 \cdot 35$ & C. & Mild, late mod \\
\hline 86 & 22 & 1075 & 190 & $2 \cdot 6$ & $3 \cdot 8$ & 42 & 41 & 0.56 & $17 \cdot 1$ & $0 \cdot 23$ & 149 & 3.65 & $T$ & 0 \\
\hline 83 & 22 & 678 & 115 & $3 \cdot 1$ & $8 \cdot 8$ & & 60 & $1 \cdot 6$ & & & 55 & 0.92 & $\mathbf{M}$ & 0 \\
\hline 75 & 26 & 996 & 160 & $3 \cdot 3$ & $6 \cdot 3$ & & 63 & $1 \cdot 3$ & & & 99 & 1.6 & C & 0 \\
\hline 63 & 28 & 780 & 199 & $3 \cdot 3$ & $9 \cdot 5$ & & 74 & $1 \cdot 23$ & & & 125 & $1 \cdot 7$ & C & Mild \\
\hline 91 & 28 & 947 & 156 & $2 \cdot 8$ & $5 \cdot 2$ & 23 & 49 & 0.88 & $11 \cdot 2$ & $0 \cdot 20$ & 107 & $2 \cdot 2$ & $\mathrm{C}$ & Mild \\
\hline 76 & 29 & 838 & 172 & $3 \cdot 0$ & $8 \cdot 5$ & 14 & 71 & $1 \cdot 24$ & 9.9 & 0.17 & 101 & $1 \cdot 4$ & $T$ & 0 \\
\hline 58 & 30 & 402 & 93 & $4 \cdot 1$ & $5 \cdot 9$ & & 24 & 1.05 & & & 69 & 2.9 & M & Severe (fatal) \\
\hline 99 & 32 & 600 & 125 & $3 \cdot 2$ & $6 \cdot 7$ & 27 & 40 & 1.00 & $10 \cdot 8$ & 0.27 & 85 & $2 \cdot 1$ & $\mathrm{C}$ & Mild \\
\hline 71 & 33 & 934 & 144 & $2 \cdot \overline{7}$ & $10 \cdot 2$ & 30 & 95 & $1 \cdot 79$ & $28 \cdot 5$ & 0.53 & 49 & 0.5 & $\mathrm{C}$ & Mild \\
\hline 89 & 36 & 1058 & 231 & $2 \cdot 9$ & $7 \cdot \overline{6}$ & 21 & 80 & $1 \cdot 0$ & $16 \cdot 8$ & 0.21 & 151 & 1.9 & $\mathrm{C}$ & Fatal \\
\hline 65 & 37 & 652 & 99 & $3 \cdot 5$ & $10 \cdot 6$ & 21 & 69 & $2 \cdot 45$ & $14 \cdot 5$ & 0.51 & 30 & 0.4 & $\mathbf{M}$ & Severe (recovery) \\
\hline 53 & 38 & 746 & 114 & $2 \cdot 4$ & $8 \cdot 6$ & & 64 & $1 \cdot 35$ & & & 50 & 0.77 & $\mathrm{C}$ & 0 \\
\hline 80 & 38 & 873 & 252 & $3 \cdot 5$ & $7 \cdot 3$ & & 60 & 0.84 & & & 192 & $3 \cdot 3$ & $\mathrm{C}$ & $\begin{array}{l}\text { Acute renal } \\
\text { failure }\end{array}$ \\
\hline 102 & 39 & 1554 & 151 & $2 \cdot 3$ & $3 \cdot 9$ & & 61 & 0.92 & & & 90 & $1 \cdot 5$ & $\mathrm{C}$ & Cardiac failure \\
\hline 93 & 40 & 1040 & 235 & $3 \cdot 2$ & $5 \cdot 2$ & 38 & 54 & 0.73 & $20 \cdot 5$ & $0 \cdot 28$ & 181 & $3 \cdot 3$ & $\mathbf{M}$ & Moderate-severe \\
\hline 66 & 42 & 820 & 184 & $3 \cdot 5$ & $6 \cdot 5$ & 26 & 53 & $1 \cdot 0$ & 13.9 & 0.26 & 131 & $2 \cdot 45$ & $\mathrm{C}$ & Chronic \\
\hline 85 & 42 & 774 & 204 & $3 \cdot 6$ & $6 \cdot 8$ & 22 & 53 & 0.93 & $11 \cdot 5$ & $0 \cdot 20$ & 151 & 2.9 & $\mathbf{M}$ & Severe (fatal) \\
\hline 78 & 46 & 952 & 206 & $3 \cdot 7$ & $4 \cdot 6$ & 40 & 44 & 0.78 & $17 \cdot 6$ & 0.31 & 162 & $3 \cdot 7$ & $\mathbf{M}$ & Mild \\
\hline 73 & 49 & 1244 & 175 & $2 \cdot 6$ & $6 \cdot 5$ & 31 & 80 & $1 \cdot 19$ & $47 \cdot 4$ & 0.70 & 95 & $1 \cdot 2$ & C & Moderate \\
\hline
\end{tabular}

*Type of graft: $\mathrm{T}=$ identical twin

$\mathrm{C}=$ compatible HLA-identical sibling

$\mathbf{M}=$ haplotype-identical mismatch.

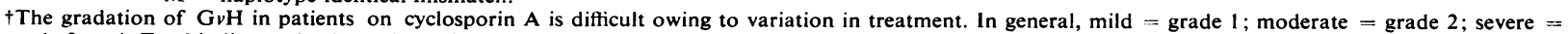
grade 3 or 4 . Fatal indicates death partly attributable to $\mathrm{Gr} H$ disease.

ARDS = adult respiratory distress syndrome. 
Table 2 Data for 13 female donor aspirates. All figures $\times 10^{8}$ unless otherwise stated

\begin{tabular}{|c|c|c|c|c|c|c|c|c|c|c|c|c|c|c|}
\hline \multirow[t]{2}{*}{ Case no } & \multirow[t]{2}{*}{ Age $(y r)$} & \multirow[t]{2}{*}{$\operatorname{Vol}(m l)$} & \multirow{2}{*}{$\begin{array}{l}\text { Total } \\
\text { cells }\end{array}$} & \multirow{2}{*}{$\begin{array}{l}\text { Cells/kg } \\
\text { recipients } \\
\text { body } \\
\text { weight }\end{array}$} & \multicolumn{2}{|l|}{ Donor } & \multirow{2}{*}{$\begin{array}{l}\text { Blood- } \\
\text { derived } \\
\text { cells } \\
(B D C)\end{array}$} & \multirow{2}{*}{$\begin{array}{l}\text { BDC/kg } \\
\text { recipients } \\
\text { body } \\
\text { weight }\end{array}$} & \multirow{2}{*}{$\begin{array}{l}\text { Blood- } \\
\text { derived } \\
\text { lymphs } \\
(B D L)\end{array}$} & \multirow{2}{*}{$\begin{array}{l}\text { BDL/kg } \\
\text { recipients } \\
\text { body } \\
\text { weight }\end{array}$} & \multirow{2}{*}{$\begin{array}{l}\text { Bone } \\
\text { marrow } \\
\text { cells } \\
(B M C)\end{array}$} & \multirow{2}{*}{$\begin{array}{l}B M C ! \\
B D C\end{array}$} & \multirow{2}{*}{$\begin{array}{l}\text { Type } \\
\text { of } \\
\text { graft }\end{array}$} & \multirow[t]{2}{*}{$G v H(e t c) \dagger$} \\
\hline & & & & & $\begin{array}{l}W B C \\
\left(\times 10^{\vartheta} / l\right)\end{array}$ & Lymphs (\%) & & & & & & & & \\
\hline 68 & 7 & 410 & 106 & $3 \cdot 5$ & $8 \cdot 8$ & 43 & 36 & $1 \cdot 20$ & $15 \cdot 5$ & 0.51 & 70 & 1.9 & C & Mild \\
\hline 92 & 13 & 710 & 163 & $3 \cdot 1$ & $6 \cdot 5$ & 33 & 46 & 0.87 & $15 \cdot 4$ & 0.29 & 117 & $2 \cdot 55$ & $\mathrm{C}$ & Mild \\
\hline 98 & 14 & 629 & 137 & $3 \cdot 1$ & $6 \cdot 1$ & & 38 & 0.87 & & & 99 & $2 \cdot 6$ & C & 0 \\
\hline 87 & 22 & 633 & 163 & $3 \cdot 4$ & $9 \cdot 3$ & & 59 & $1 \cdot 23$ & & & 104 & $1 \cdot 77$ & $\mathrm{C}$ & 0 \\
\hline 62 & 22 & 938 & 183 & $3 \cdot 1$ & 6.5 & 20 & 61 & 1.03 & $12 \cdot 2$ & 0.21 & 122 & $2 \cdot 0$ & C & Mild \\
\hline 56 & 24 & 570 & 168 & $3 \cdot 1$ & $4 \cdot 8$ & 11 & 27 & 0.50 & 3.0 & 0.05 & 141 & $5 \cdot 1$ & $\mathrm{C}$ & 0 \\
\hline 101 & 33 & 943 & 161 & $2 \cdot 5$ & $5 \cdot 0$ & 21 & 47 & 0.72 & $9 \cdot 8$ & 0.15 & 114 & $2 \cdot 4$ & $\mathrm{C}$ & 0 \\
\hline 100 & 36 & 1126 & 176 & $3 \cdot 0$ & $7 \cdot 0$ & 42 & 79 & $1 \cdot 36$ & $33 \cdot 1$ & 0.57 & 107 & $1 \cdot 35$ & C & Fatal \\
\hline 97 & 37 & 938 & 237 & $3 \cdot 3$ & $7 \cdot 6$ & 30 & 71 & $1 \cdot 0$ & $21 \cdot 4$ & 0.30 & 165 & $2 \cdot 3$ & $\mathbf{T}$ & 0 \\
\hline 84 & 38 & 896 & 207 & $2 \cdot 6$ & $7 \cdot 0$ & 35 & 63 & 0.79 & 22.0 & $0 \cdot 28$ & 144 & $2 \cdot 3$ & $\mathrm{C}$ & Mild \\
\hline 57 & 43 & 941 & 146 & $2 \cdot 2$ & $8 \cdot 3$ & & 78 & $1 \cdot 18$ & & & 68 & 0.87 & $\mathrm{C}$ & Mild, late mod \\
\hline 64 & 43 & 1350 & 104 & $2 \cdot 2$ & $3 \cdot 2$ & & 70 & $1 \cdot 48$ & & & 34 & 0.5 & $\mathbf{M}$ & ARDS \\
\hline 90 & 52 & 776 & 172 & $3 \cdot 1$ & $4 \cdot 0$ & 38 & 31 & 0.56 & $11 \cdot 8$ & 0.21 & 141 & $4 \cdot 6$ & $\mathbf{M}$ & ARDS \\
\hline
\end{tabular}

* +See footnotes to Table 1.

the incidence of $\mathrm{G} v \mathrm{H}$ disease in compatible transplants with either the total number of blood-derived cells or the bone-marrow to blood-derived cell ratio. Possibly the total number of lymphocytes bears some relation since all five who received $0.5 \times 10^{8}$ or more blood lymphocytes from the donor had some degree of $\mathrm{G} v \mathrm{H}$ disease but the converse does not hold since case No 89 , receiving only $0.21 \times 10^{8}$ lymphocytes, developed fatal $\mathrm{G} v \mathrm{H}$ disease. In the mismatched transplants the importance of blood leucocytes in the genesis of $\mathrm{G} v \mathrm{H}$ disease or the acute mismatch syndrome is not apparent, although one major cause of death in such patients-adult respiratory distress syndrome (ARDS) - might be immunologically mediated. It is seen in patients having cyclosporin-A and appears to be much commoner after mismatched transplants than after fully matched transplants.

\section{Discussion}

These results show that bone-marrow aspirates as used in transplantation vary by as much as twelvefold in their relative content of marrow-derived and blood-derived cells. This variation may not affect the proportion of graft rejections and takes, provided the total number of cells is adequate since it was shown by Deeg et al ${ }^{5}$ that in dogs viable lymphocytes from blood or thoracic duct, if added to suboptimal numbers of allogeneic marrow cells, could contribute to the acceptance of the graft-but at a cost in the incidence of subsequent $\mathrm{G} v \mathrm{H}$ disease. What might be expected is that $\mathrm{G} v \mathrm{H}$ disease would more frequently follow grafts with low marrow to blood cell ratios, but that has not been our experience. Possibly the lack of correlation is due to the small number of cases and the infrequency of $\mathrm{G} v \mathrm{H}$ disease in this series. Furthermore, the propensity of marrow from female donors to cause $\mathrm{G} v \mathrm{H}$ disease ${ }^{4}$ cannot be attributed to any systematic difference in the ratio of marrow to blood cells and that phenomenon remains unexplained. One possible explanation is that female marrow contains more lymphoid cells, for which there is evidence. Rywlin et $a l^{6}$ analysed the proportion of marrow aspirates containing lymphoid nodules and found that $53 \%$ of female marrows contained them, compared with only $41 \%$ of male marrows - these in addition to patients with nodular lymphoid hyperplasia (without lymphoma) where there were eight females against two males. Admittedly, the sample was mostly from an older age group than that from which bone marrow donors are recruited but it suggests a possible basis for the incidence of $\mathrm{G} v \mathrm{H}$ disease in relation to donor sex.

In our study an attempt was made to count lymphoid cells in smears from the marrow suspensions but owing to morphological ambiguities this is an inaccurate procedure. The figures suggested that more lymphocytes were present than could be accounted for by the blood component but an analysis by section of particles or by specific lymphocyte markers would probably be more accurate. Current methods of marrow transplantation using antilymphocyte sera or lectins to remove lymphocytes might also indicate the basis of the sex difference in marrow transplants.

The transplants were carried out by the Transplant Team of the Leukaemia Unit at the Royal Marsden Hospital. This work is supported by the Leukaemia Research Fund and the Bud Flanagan Leukaemia Fund. Their support and the efforts of all those concerned is gratefully acknowledged.

\section{References}

${ }^{1}$ Goodman Joan W, Congdon CC. Blood-marrow mixtures 
in irradiated mice. Arch Pathol 1961 ;72:18-26.

${ }^{2}$ Grebe SC, Streilein JW. Graft versus host reactions: a review. In: Dixon FJ, Kunkel HG, eds. Advances in immunology. New York: Academic Press, 1976:119-21.

${ }^{3}$ Elkins WL. Effector mechanisms and graft versus host disease. Transplant Proc 1978:10:15-7.

4 Bortin MM, Rimm AA. Treatment of 144 patients with severe aplastic anemia using immunosuppression and allogeneic marrow transplantation: A report from the International Bone Marrow Transplant Registry. Transplant Proc 1981 ;XIII, 1 :227-9.

${ }^{5}$ Deeg HJ, Storb R, Weiden PL, et al. Abrogation of resistance and enhancement of DLA-non-identical unrelated marrow grafts in lethally irradiated dogs by thoracic duct lymphocytes. Blood 1979;53:552-7.

${ }^{6}$ Rywlin AM, Ortego RS, Dominguez CJ. Lymphoid nodules of bone-marrow: normal and abnormal. Blood 1974;43:389-400.

Requests for reprints to: Dr HEM Kay, Leukaemia Unit, Royal Marsden Hospital, Fulham Road, London SW3 6JJ, England. 